\title{
Planktic foraminiferal shell thinning in the Arabian Sea due to anthropogenic ocean acidification?
}

\author{
H. de Moel ${ }^{1,2}$, G. M. Ganssen ${ }^{1}$, F. J. C. Peeters ${ }^{1}$, S. J. A. Jung ${ }^{1,3}$, D. Kroon ${ }^{1,3}$, G. J. A. Brummer ${ }^{4}$, and R. E. Zeebe \\ ${ }^{1}$ Department of Paleoclimatology and Geomorphology, Vrije Universiteit Amsterdam, de Boelelaan 1085, 1081 HV, \\ Amsterdam, The Netherlands \\ ${ }^{2}$ Institute for Environmental Studies, Vrije Universiteit Amsterdam, de Boelelaan 1085, $1081 \mathrm{HV}$, Amsterdam, \\ The Netherlands \\ ${ }^{3}$ School of GeoSciences, University of Edinburgh, Grant Institute, The King's Buildings, West Mains Road, \\ Edinburgh EH9 3JW, UK \\ ${ }^{4}$ Department of Marine Geology, Royal Netherlands Institute for Sea Research, P.O. Box 59, 1790 AB, Den Burg, \\ The Netherlands \\ ${ }^{5}$ School of Ocean and Earth Science and Technology, Department of Oceanography, University of Hawaii at Manoa, 1000 \\ Pope Road, MSB504, Honolulu, HI 96822, USA
}

Received: 17 December 2008 - Published in Biogeosciences Discuss.: 9 February 2009

Revised: 3 June 2009 - Accepted: 24 August 2009 - Published: 23 September 2009

\begin{abstract}
About one third of the anthropogenic carbon dioxide $\left(\mathrm{CO}_{2}\right)$ released into the atmosphere in the past two centuries has been taken up by the ocean. As $\mathrm{CO}_{2}$ invades the surface ocean, carbonate ion concentrations and $\mathrm{pH}$ are lowered. Laboratory studies indicate that this reduces the calcification rates of marine calcifying organisms, including planktic foraminifera. Such a reduction in calcification resulting from anthropogenic $\mathrm{CO}_{2}$ emissions has not been observed, or quantified in the field yet. Here we present the findings of a study in the Western Arabian Sea that uses shells of the surface water dwelling planktic foraminifer Globigerinoides ruber in order to test the hypothesis that anthropogenically induced acidification has reduced shell calcification of this species. We found that light, thin-walled shells from the surface sediment are younger (based on ${ }^{14} \mathrm{C}$ and $\delta^{13} \mathrm{C}$ measurements) than the heavier, thicker-walled shells. Shells in the upper, bioturbated, sediment layer were significantly lighter compared to shells found below this layer. These observations are consistent with a scenario where anthropogenically induced ocean acidification reduced the rate at which foraminifera calcify, resulting in lighter shells. On the other hand, we show that seasonal upwelling in the area also influences their calcification and the stable isotope $\left(\delta^{13} \mathrm{C}\right.$ and $\left.\delta^{18} \mathrm{O}\right)$ signatures recorded by the foraminifera shells. Plankton tow and sediment trap data show that lighter shells were
\end{abstract}

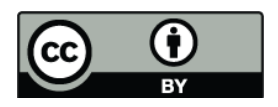

Correspondence to: H. de Moel (hans.de.moel@ivm.vu.nl) produced during upwelling and heavier ones during nonupwelling periods. Seasonality alone, however, cannot explain the ${ }^{14} \mathrm{C}$ results, or the increase in shell weight below the bioturbated sediment layer. We therefore must conclude that probably both the processes of acidification and seasonal upwelling are responsible for the presence of light shells in the top of the sediment and the age difference between thick and thin specimens.

\section{Introduction}

Over the course of the late Pleistocene, atmospheric $\mathrm{CO}_{2}$ concentrations fluctuated between $180 \mathrm{ppm}$ and $280 \mathrm{ppm}$ during glacial and interglacial time periods, respectively (Petit et al., 1999; Luthi et al., 2008). As atmospheric and surface ocean $\mathrm{CO}_{2}$ equilibrate on a time scale of $\sim 1$ year, dissolved $\mathrm{CO}_{2}(\mathrm{aq})$ in surface seawater changes proportionally. Such perturbations in dissolved $\mathrm{CO}_{2}$ directly affect the equilibrium between the three different forms of total dissolved inorganic carbon (DIC)(Zeebe and Wolf-Gladrow, 2001): aqueous carbon dioxide $\left(\mathrm{CO}_{2}(\mathrm{aq})\right)$, bicarbonate $\left(\mathrm{HCO}_{3}^{-}\right)$, and carbonate ion $\left(\mathrm{CO}_{3}^{2-}\right)$. As $\mathrm{CO}_{2}$ invades the surface ocean, seawater becomes less alkaline. Consequently, the $\mathrm{pH}$ and carbonate ion concentration $\left(\left[\mathrm{CO}_{3}^{2-}\right]\right)$ of surface seawater, and subsequently of deep water, is lowered (WolfGladrow et al., 1999), a process referred to as 'ocean acidification'. During the late Pleistocene interglacial periods,

Published by Copernicus Publications on behalf of the European Geosciences Union. 


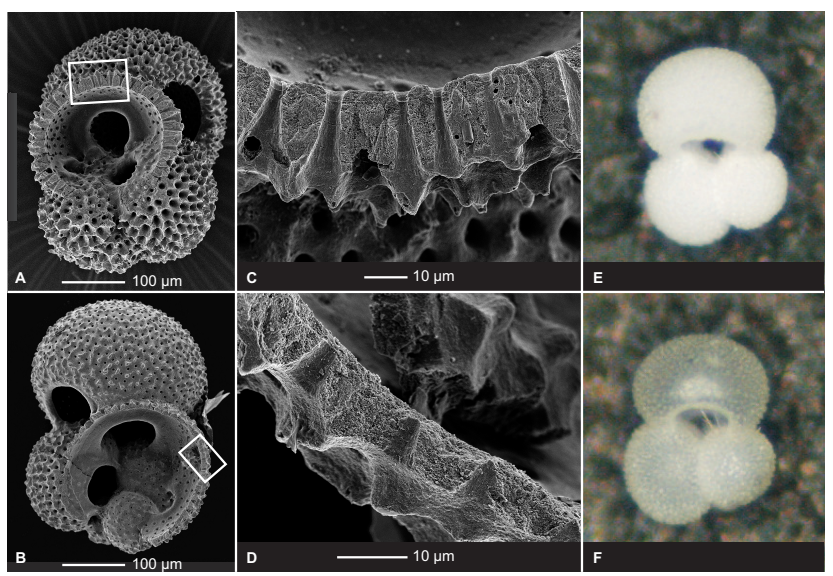

Fig. 1. Scanning Electron Microscope (SEM) images of a thick (A) and thin (B) walled shell, with a close-up of the cross-section of the shell wall (C-D) as well as microphotographs of a thick (E) and thin (F) specimen. Note that the cross-section of the thin specimen (D) has a larger magnification than the thick specimen (C). The difference in wall thickness between these two specimens is above the measured average (see Table 1).

as well as today, higher atmospheric $\mathrm{CO}_{2}$ concentrations $\left(\mathrm{pCO}_{2}\right)$ signify higher $\mathrm{CO}_{2}(\mathrm{aq})$ concentrations, lower $\mathrm{pH}$, and lower $\left[\mathrm{CO}_{3}^{2-}\right]$. Laboratory studies have shown that lower $\left[\mathrm{CO}_{3}^{2-}\right]$ reduces the calcification rates of marine calcifyers like foraminifera (Bijma et al., 1999), corals (Langdon and Atkinson, 2005), coccolithophores (Riebesell et al., 2000), and shellfish (Gazeau et al., 2007). This reduction in calcification forced by increased $\mathrm{pCO}_{2}$ has also been observed in the geological past by, for example, Barker and Elderfield (2002) who reported a decrease in the shell weight of planktic foraminifera over the last deglaciation.

The recent increase in atmospheric $\mathrm{CO}_{2}$, due to fossil fuel burning and increased land use changes, is comparable in magnitude to the changes found between glacials and interglacials $(\sim 90 \mathrm{ppm})$ (Etheridge et al., 1998; Petit et al., 1999). About one third of this anthropogenic $\mathrm{CO}_{2}$ has been taken up by the ocean (Sabine et al., 2004), changing the carbonate chemistry of the seawater. One can therefore expect that modern calcification rates have decreased because of anthropogenic ocean acidification. Such an effect of anthropogenic ocean acidification on the marine biosphere is, however, not documented yet (Rosenzweig et al., 2007). Researchers working with foraminifera have observed, though never documented, that foraminifera from the water column appear to be thinner shelled and more transparant compared to specimens found in the sediment: an observation that may be related to the effects of anthropogenic ocean acidification.

In this paper we investigate the potential effect of anthropogenic ocean acidification on shell weights and wall thickness of the planktic foraminifer Globigerinoides ruber in the Western Arabian Sea. Assuming that anthro- pogenic acidification has decreased calcification rates of planktic foraminifera, resulting in lower shell weights and more transparant shells (i.e. the decrease in calcification led to thinner shell walls and not smaller tests), the following two hypotheses can be formulated. (1) The average shell weight in the modern surface sediments should be lower than in older sediment sections downcore (weight hypothesis). (2) Simultaneously, light-weight shells in the surface sediment should be younger than the heavier ones found in the surface sediment (age hypothesis). In this paper we demonstrate a methodological framework to address the above hypotheses and we use material from two box-cores to test these hypotheses. Additionally, sediment trap data from the same site are used to put the observations into a perspective of seasonal variability. The material has been taken off the coast of Somalia in the Arabian Sea, a site chosen because of its high sedimentation rate $(\sim 20 \mathrm{~cm} / \mathrm{ka}$, Ivanova et al., 2000$)$ and high abundance of fossil G. ruber.

\section{Methods}

During the Netherlands Indian Ocean Program (NIOP) cruises in 1992 and 1993, to the North western Indian ocean, two box-cores, BC21WP7 and 905B, were taken at site 905 off Somalia from a depth op 1617 and $1567 \mathrm{~m}$, respectively (NIOP, 1995). Site 905 is characterized by a high sedimentation rate, about $20 \mathrm{~cm} / \mathrm{ky}$ (Ivanova, 1999), and seasonal upwelling. For the "weight hypothesis" samples from core 905B were examined. Average shell weights (of around 80 individual shells) were measured at various levels in boxcore 905B for both the $250-300$ and $300-355 \mu \mathrm{m}$ size fractions. In order to estimate the mixing depth ${ }^{210} \mathrm{~Pb}$ activities were determined indirectly by $\alpha$ spectrometry using the granddaughter ${ }^{210} \mathrm{Po}$ (Van Weering et al., 1987) and evaluating different ${ }^{210} \mathrm{~Pb}$ mixing models (Soetaert et al., 1996).

In order to address the "age hypothesis", the 250-500 $\mu \mathrm{m}$ size fraction from the uppermost centimeter of box-core BC21WP7 was used. From this fraction all Globerigenoides ruber shells were picked and divided into different groups according to their relative transparency. Average shell weights were determined for these groups and several opaque and transparant specimens were analysed using a Scanning Electron Microscope (SEM) to determine shell thickness (Fig. 1) and to look for traces of dissolution. Morphological examination showed that the opaque and transparent groups contain equal proportions of the morphotypes $G$. ruber sensu stricto and G. ruber sensu lato (Wang, 2000) (approximately $25 \%$ and $75 \%$, respectively). A size analysis showed that the transparent and opaque shells have identical size distributions (see Supplementary Data: http://www.biogeosciences. net/6/1917/2009/bg-6-1917-2009-supplement.zip).

In order to determine the relative age of the opaque and transparent shells, radiocarbon analyses were performed. During the late 1950s and early 1960s, high amounts of 
${ }^{14} \mathrm{C}$ were put into the atmosphere during nuclear bomb tests (Broecker and Olson, 1960), which is recorded by carbonate in the surface ocean (Grumet et al., 2004, 2002; Kalish et al., 2001). This finding allows to distinguish between carbonate sequestered before and after those bomb tests. For this study radiocarbon was measured on a sample of 795 transparent shells, and on one of 657 opaque shells from the core top sediment.

Stable carbon isotopes $\left(\delta^{13} \mathrm{C}\right)$ can be used in a similar way to determine the relative age between the opaque and transparent shells. Whilst the $\delta^{13} \mathrm{C}$ signal itself is subject to many different factors and processes, it draws from the $\delta^{13} \mathrm{C}$ of dissolved inorganic carbon (DIC) in the seawater (Spero, 1992). Because carbon sequestered by photosynthesis, and thus fossil fuels, are strongly depleted in ${ }^{13} \mathrm{C}$ ( $\sim 25 \%$, O'Leary, 1981), the continued burning of fossil fuels has decreased the $\delta^{13} \mathrm{C}$ of atmosphere $\mathrm{CO}_{2}$ over the last two centuries. This process, known as the 'Suess effect', has been observed through direct measurements (Keeling et al., 1979), in tree rings (February and Stock, 1999; Feng and Epstein, 1995; Leavitt and Lara, 1994), and ice cores (Francey et al., 1999; Friedli et al., 1986). This ${ }^{13} \mathrm{C}$ depleted anthropogenic $\mathrm{CO}_{2}$ also invades the surface ocean, lowering the $\delta^{13} C_{\text {DIC }}$ (Kortzinger et al., 2003; Quay et al., 2003; Gruber et al., 1999), which is taken up during calcification by planktic foraminifera (i.e. Beveridge and Shackleton, 1994). Consequently, $\delta^{13} \mathrm{C}$ can be used as a relative dating tool to distinguish between shells that calcified before or since the industrial revolution. Around 150 shells were analysed individually on stable isotopes composition, taken from both groups and from size fractions 250-300, 300-355, 355-400, and $400-500 \mu \mathrm{m}$.

\section{Results}

\subsection{Analyses for the weight hypothesis}

The ${ }^{210} \mathrm{~Pb}$ profile shows a mixing depth of $\sim 15 \mathrm{~cm}$ (see Supplementary Data: http://www.biogeosciences.net/ 6/1917/2009/bg-6-1917-2009-supplement.zip), which coincides with an increase in shell weight below this depth (Fig. 2). Average shell weights within the upper $15 \mathrm{~cm}$ are $1.7 \mu \mathrm{g}$ lighter compared to the shells found farthest down core $(21$ to $27 \mathrm{~cm})$. These down core shells are in turn $1.5 \mu \mathrm{g}$ lighter compared to shell weights from the last glacial maximum (Fig. 2). This distribution of shell weights through the sediment core is in line with a scenario where acidification has reduced calcification rates. Light weight shells would have rained down on the ocean floor and mixed into the upper $15 \mathrm{~cm}$ (mixed layer). This would have lowered the average shell weight in the mixed layer compared to the weight of shells below the mixed layer, which all calcified during preindustrial times and have not been part of the mixed layer since. The difference in average shell weight of specimens

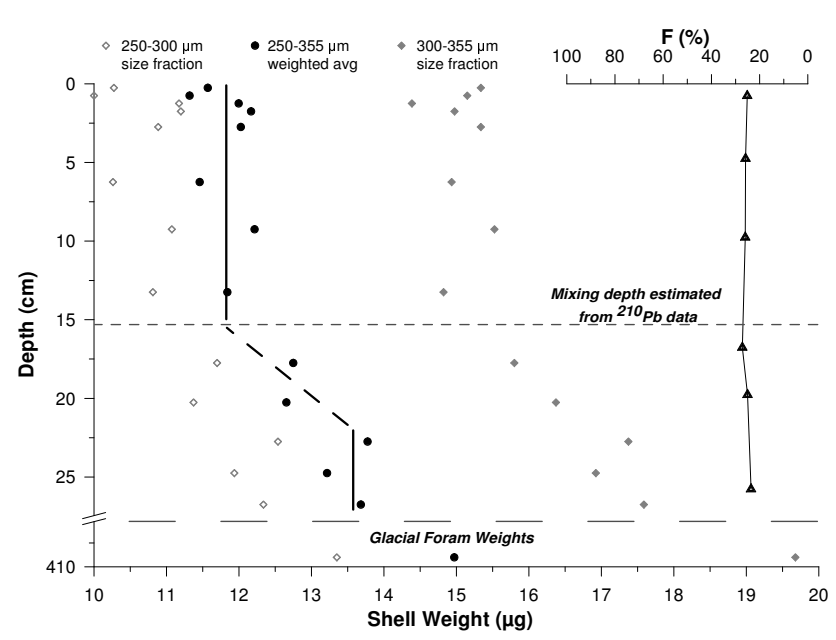

Fig. 2. Average weight of $G$. ruber shells $(250-355 \mu \mathrm{m})$ in sediment core $905 \mathrm{~B}$ and fragmentation index $F(\%)$. Size fractions of 250-300 $\mu \mathrm{m}$ (grey open diamond) and 300-355 $\mu \mathrm{m}$ (grey closed diamonds) have been measured separately for each sample. The 250-355 $\mu \mathrm{m}$ weights (black closed circles) have been determined using the relation found in the core-top sample between the two measured fractions. The glacial shell weight was determined from a piston core sample taken at the same site (905P, $409 \mathrm{~cm}$ depth), and corresponds to an age of approximately 16600 years BP (Jung et al., 2002). Dissolution coefficient $F(\%)$, a ratio of whole versus fragmented foraminifera, is calculated from data of Conan et al. (2002) from sediment core 905B.

from within the sediment mixed layer and from below is significant at the $99 \%$ confidence level.

\subsection{Analyses for the age hypothesis}

The results of the analyses performed on the thick and thin shells from the top cm of box-core BC21WP7 are summarised in Table 1. The transparent shells weigh on average $\sim 3.3 \mu \mathrm{g}$ less than the opaque ones in the $250-500 \mu \mathrm{m}$ size fraction. As the size distributions of both groups are identical, this is not a result of smaller or larger tests. In addition to being lighter, the transparent group is characterised by shell walls that are, on average, $\sim 5 \mu \mathrm{m}$ thinner. As the relative decrease in shell weight $(-25 \%)$ and wall thickness $(-30 \%)$ is similar, we conclude that the lower shell weight is primarily a result of thinner chamber walls.

The radiocarbon results show that the group of transparent/thin shells has enhanced, above $100, F^{14} \mathrm{C}$ (or pMC: percent Modern Carbon) values and a negative radiocarbon age. As radiocarbon ages are relative to 1950 , before the nuclear tests, this negative age and an $F^{14} \mathrm{C}$ value above 100 indicates that the thin shells contain high amounts of bomb carbon. The thick shells from the same sample, on the other hand, have a positive radiocarbon age and lower $F^{14} \mathrm{C}$ value, indicating that these shells contained less bomb carbon (or rather: less shells contained bomb carbon) compared to the 
Table 1. Results of analyses on the thick and thin walled G. ruber populations from the core top of BC21WP7. Values represent average values, number of specimens or measurements $(n)$, and one standard deviation where possible $( \pm)$.

\begin{tabular}{llllllr}
\hline & $\begin{array}{l}\text { Foram Weight } \\
(\mu \mathrm{g})\end{array}$ & $\begin{array}{l}\text { Shell Wall Thickness } \\
(\mu \mathrm{m})\end{array}$ & $\begin{array}{l}\delta^{18} \mathrm{O} \\
(\% \circ \mathrm{VPDB})\end{array}$ & $\begin{array}{l}\delta^{13} \mathrm{C} \\
(\% \circ \mathrm{VPDB})\end{array}$ & $\begin{array}{r}F^{14} \mathrm{C} \\
\begin{array}{l}{ }^{14} \mathrm{C} \text { Age } \\
(\mathrm{yr} \mathrm{BP})\end{array}\end{array}$ \\
\hline $\begin{array}{l}\text { Thick } \\
\text { Foraminifera }\end{array}$ & $13.42(n=657)$ & $17 \pm 3.7(n=8)$ & $-1.98 \pm 0.39(n=67)$ & $0.83 \pm 0.33(n=67)$ & 0.9834 & $135 \pm 25$ \\
$\begin{array}{l}\text { Thin } \\
\text { Foraminifera }\end{array}$ & $10.08(n=795)$ & $12 \pm 3.4(n=6)$ & $-1.78 \pm 0.63(n=80)$ & $0.47 \pm 0.36(n=80)$ & 1.0415 & $-325 \pm 25$ \\
\hline
\end{tabular}

thin group. This would suggest that the thin shells are on average younger compared to the thick ones.

The stable isotope measurements are also shown in Table 1 . The mean oxygen isotope values are (in the absence of ice volume changes), usually interpreted as a temperature indicator and differ by $0.2 \%$ between the two groups. This difference is statistically significant at the $95 \%$ confidence level, but not at the $99 \%$ confidence level. The carbon isotopes, on the other hand, are statistically significantly different (99\% confidence level), with the thin shells having $\delta^{13} \mathrm{C}$ values $0.36 \%$ o lower compared to the thick ones. Considering that the Suess effect has decreased the $\delta^{13} \mathrm{C}_{\mathrm{DIC}}$ since the industrial revolution, this indicates that the thick shells are older compared to the thin ones. Hence, both the radiocarbon and $\delta^{13} \mathrm{C}$ data are consistent with the acidification age hypothesis.

\subsection{Age difference estimates}

We have shown that the relative age estimates, using ${ }^{14} \mathrm{C}$ and $\delta^{13} \mathrm{C}$, indicate that the thin shells were formed more recently compared to the thick ones. To put this age difference in perspective the results can be compared to records $F^{14} \mathrm{C}$ and $\delta^{13} \mathrm{C}$ records over the last 150 years. A $F^{14} \mathrm{C}$ curve was created based on the Watamu coral record, a record from the Kenyan coast in the same water mass as the box-core site (Grumet et al., 2002), and supplemented by Marine 04 data for the pre-bomb part (Hughen et al., 2004). Relating the $F^{14} \mathrm{C}$ values of the thick and thin shells to this curve shows that both samples are between pre-bomb and postbomb values (Fig. 3a). As the samples contained around 650 and 800 individual shells, respectively, this suggests that the sample predominantly harbouring thin walled shells included more post-bomb specimens $(\sim 65 \%)$ than the sample with thick shells $(\sim 25 \%)$. Considering pre- and post-bomb shells as two end members and assuming a constant flux of foraminifera through time we can calculate an average age of $\sim 1935$ for the thick shells and of $\sim 1970$ for the thin shelled populations. Considering the large amount of individual shells per sample, these two averages are statistically significantly different.
As there is no specific $\delta^{13} \mathrm{C}$ record available for the Somali basin, the $\delta^{13} \mathrm{C}$ history is based on a compilation of studies from various oceans and time periods, using direct measurements of $\delta^{13} \mathrm{C}_{\text {DIC }}$ (Gruber et al., 1999; Stuiver and Ostlund, 1983; Key and Quay, 2002; Quay et al., 2003, 1992; Moos, 2000; Kortzinger et al., 2003), coral records (Kuhnert et al., 1999; Nozaki et al., 1978; Asami et al., 2005) and sponge records (Druffel and Benavides, 1986; Bohm et al., 2002, 1996). As work in the Pacific ocean (Gruber et al., 1999) has shown that in upwelling areas the Suess effect is less pronounced, the lower end estimates taken from these studies were used to reconstruct the $\delta^{13} \mathrm{C}$ history of the Somali basin (Fig. 3b). Besides the Suess effect, there is however another effect that influences the $\delta^{13} \mathrm{C}$ of foraminifera during the anthropogenic era. Changes in atmospheric $\mathrm{CO}_{2}$ $\left(\mathrm{pCO}_{2}\right)$ itself alter the equilibrium of carbon species in the surface water, including $\left[\mathrm{CO}_{3}^{2-}\right]$, which affects the $\delta^{13} \mathrm{C}_{\text {foram }}$ at a rate of about $-0.006 \% / \mu \mathrm{mol} / \mathrm{kg} \mathrm{CO}_{2}$ (Spero et al., 1997; Peeters et al., 2002). An increase in $\mathrm{pCO}_{2}$ would increase the $\delta^{13} C_{\text {foram }}$ where the Suess effect would lower the $\delta^{13} C_{\text {foram }}$. As the analyses reveal lower $\delta^{13} \mathrm{C}$ for the thin foraminifera, the Suess effect must have outweighed the $\mathrm{pCO}_{2}$ effect. Using the reconstructed $\delta^{13} \mathrm{C}$ curve and assuming an average age of the thin shells of 1970, an age difference between the thick and thin shells of about 140 years is calculated (Fig. 3b). Note that the age difference inferred from the radiocarbon analyses is much lower, signifying that there are considerable uncertainties in both methods. The $\delta^{13} \mathrm{C}$ estimate, for example, is very sensitive to the chosen curve and assumed age of the thin shells.

The age difference estimated above correspond to differences in $\left[\mathrm{CO}_{3}^{2-}\right]$ of 6.5 (35 years) and 18 (140 years) $\mu \mathrm{mol}^{-1} \mathrm{~kg}^{-1}$. Considering that the difference in weight between the two groups is $3.3 \mu \mathrm{g}$, this corresponds to a decrease in shell weight of 0.18 and $0.50 \mu \mathrm{g} \mathrm{mol}^{-1} \mathrm{~kg}^{-1}$ $\left[\mathrm{CO}_{3}^{2-}\right]$. Especially the lower end of this range (corresponding to the larger age difference) is similar to reduction rates based on laboratory experiments (Bijma et al., 1999) and changes in carbon chemistry during the last glacialinterglacial transition (Barker and Elderfield, 2002). 


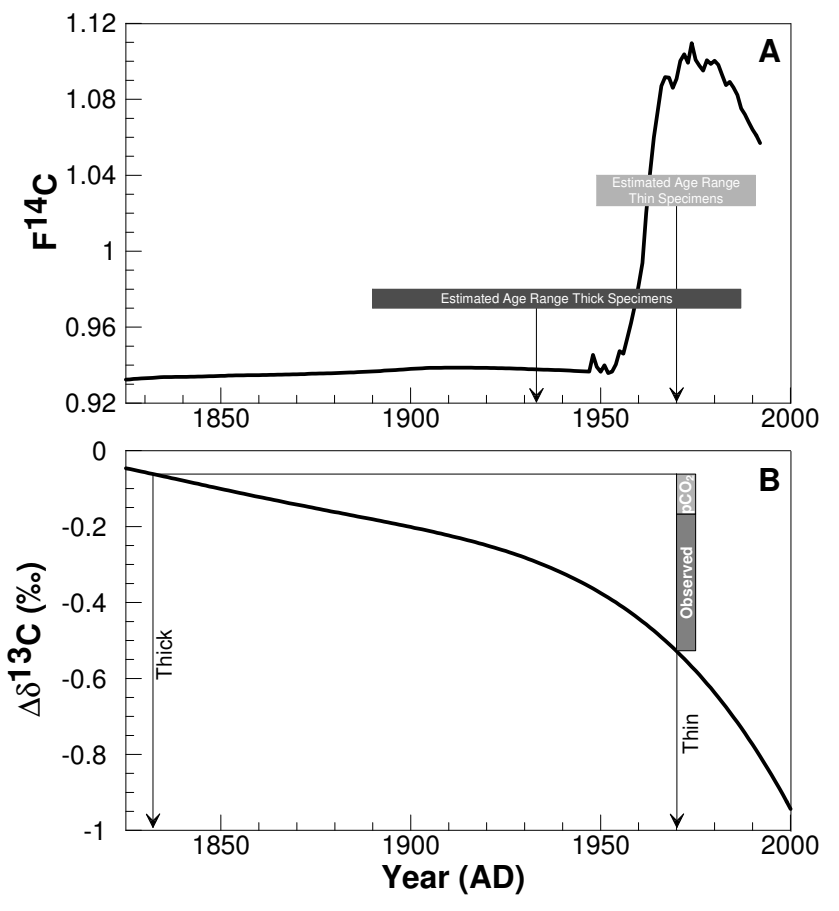

Fig. 3. Calendar age estimates. $F^{14} \mathrm{C}$ and $\delta^{13} \mathrm{C}$ curves constructed for site 905 and the corresponding age estimates. (A) The $F^{14} \mathrm{C}$ curve is mainly based on the Watamu coral record (Grumet et al., 2002), supplemented with Marine04 data (Hughen et al., 2004) and recalculated to $F^{14} \mathrm{C}$ values. The boxes represent the age range of individual shells within the samples that correspond to the measured ${ }^{14} \mathrm{C}$ age. (B) The $\delta^{13} \mathrm{C}$ curve has been derived from global measurements, coral and sponge records, taking the lower end of these estimates because of the upwelling nature of the site. The two boxes represent the $\Delta \delta^{13} \mathrm{C}$ contribution of $\left[\mathrm{CO}_{3}^{2-}\right]$ (box ' $\mathrm{pCO}_{2}$ '), and the observed difference in $\delta^{13} \mathrm{C}$ to the total Suess effect. A factor of $-0.006 \% \circ \delta^{13} \mathrm{C}$ per $\mu \mathrm{mol} / \mathrm{kg}\left[\mathrm{CO}_{3}^{2-}\right]$ has been used to calculate the effect of the carbonate ion concentration on $\delta^{13} \mathrm{C}$ (Spero et al., 1997; Peeters et al., 2002).

\subsection{Seasonal variability}

Conan (2006) analysed sediment trap samples from the Arabian Sea, covering a time span of nine months. These results show a pronounced seasonal signal in $\delta^{18} \mathrm{O}$ and $\delta^{13} \mathrm{C}$, and to a lesser extent in shell weight (Fig. 4). Flux corrected averages for shell weight, $\delta^{18} \mathrm{O}$ and $\delta^{13} \mathrm{C}$ for the monsoonal and inter-monsoonal period of the sediment trap record all test significantly different at $95 \%$ confidence level, with the shells produced during the upwelling season having lower shell weight, higher $\delta^{18} \mathrm{O}$ and lower $\delta^{13} \mathrm{C}$ values (Table 2).

\section{Discussion}

We have shown above that the data for box-core 905B (shell weights) and between thick and thin specimens in the nearby box-core BC21WP7 (shell weights, wall thickness, stable

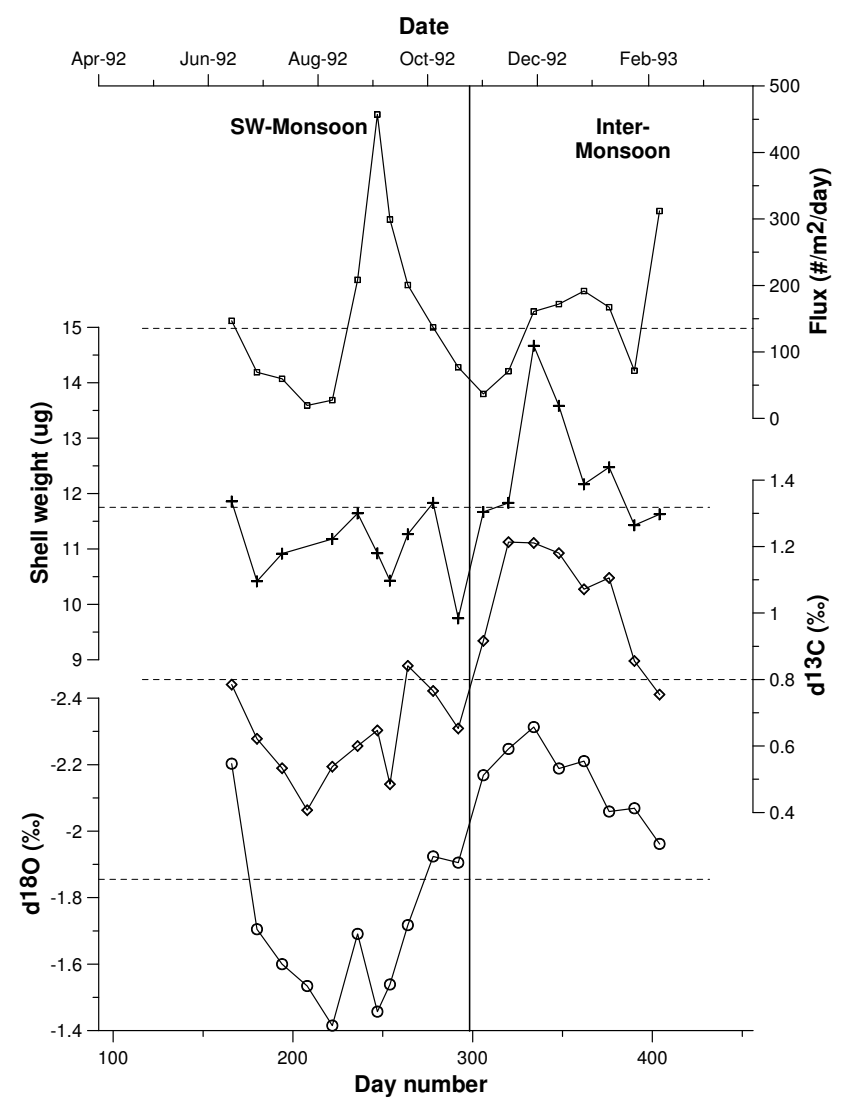

Fig. 4. Sediment Trap Data. Flux, shell weight, $\delta^{13} \mathrm{C}$, and $\delta^{18} \mathrm{O}$ from a 9 month sediment trap record (MST8B) taken at site 905 from June 1992 to February 1993 (Conan, 2006). Division between monsoon and inter-monsoon based on G. bulloides flux measured from the same samples. Weight and stable isotopes were measured on samples of about 13 specimens each in the size fraction of 250$355 \mu \mathrm{m}$. The dashed lines represent the 9 month flux corrected averages.

isotope composition and radiocarbon signature) favour the hypothesis that the anthropogenic increase in $\mathrm{CO}_{2}$ has caused a decrease in calcification over the last century. The sediment trap results, however, show that seasonality produces seasonal differences in shell weight and stable isotopes as well. Furthermore, there are other factors, besides acidification and seasonality, which could potentially play a role in the interpretation of our results. These different explanations will be discussed below in the light of our results.

\subsection{Post-depositional calcification}

The difference in weight between thick and thin shells could also be the result of post-depositional calcification on the ocean floor (i.e. by diagenetic precipitation). This could explain the older ${ }^{14} \mathrm{C}$ age for the thick shells as the additional carbonate would have precipitated in older bottom waters, adjusting the signatures accordingly. However, bottom water 
Table 2. Shell weight, $\delta^{18} \mathrm{O}$, and $\delta^{13} \mathrm{C}$ data of G. ruber for size fraction $255-350 \mu \mathrm{m}$ for specimens from a 9 month sediment trap record (divided into a monsoonal and inter-monsoonal period), thick and thin specimens from the top of sediment core BC21WP7, surface water (plankton tow), and from the mixed layer and below the mixed layer of sediment core 905B). * Averages of the trap data are flux corrected, but the standard deviations could not be flux corrected so the uncorrected values are given in this table to give an indication. ${ }^{* *}$ For shell weight $\mid$ stable isotopes.

\begin{tabular}{lcccl}
\hline $\begin{array}{l}\text { G. ruber } \\
(255-350 \mu \mathrm{m})\end{array}$ & $\begin{array}{c}\text { Shell Weight } \\
(\mu \mathrm{g})\end{array}$ & $\begin{array}{c}\delta^{18} \mathrm{O} \\
(\% \circ \mathrm{VPDB})\end{array}$ & $\begin{array}{c}\delta^{13} \mathrm{C} \\
(\% \circ \mathrm{VPDB})\end{array}$ & $\begin{array}{l}\text { \# of analyses } \\
\text { averaged }\end{array}$ \\
\hline Trap - Monsoon & $11.1 \pm 0.68^{*}$ & $-1.67 \pm 0.23^{*}$ & $0.65 \pm 0.13^{*}$ & 10 \\
Trap - Inter-monsoon & $12.5 \pm 1.13^{*}$ & $-2.13 \pm 0.11^{*}$ & $1.02 \pm 0.18^{*}$ & 8 \\
& & & & \\
Top core - Thin shells & 9.7 & $-1.74 \pm 0.67$ & $0.43 \pm 0.35$ & $1 \mid 64^{* *}$ \\
Top core - Thick shells & 12.9 & $-1.97 \pm 0.40$ & $0.78 \pm 0.33$ & $1 \mid 55^{* *}$ \\
& & & & \\
Plankton Tow & $11.5 \pm 0.69$ & n.a. & n.a. & 6 \\
Trap - 9 months & $11.7 \pm 1.14^{*}$ & $-1.86 \pm 0.30^{*}$ & $0.80 \pm 0.26^{*}$ & 18 \\
Sediment - Mixed Layer & $11.8 \pm 0.34$ & n.a. & n.a. & 8 \\
Sediment - Below ML & $13.6 \pm 0.30$ & n.a. & n.a. & 3 \\
\hline
\end{tabular}

is also significantly colder than surface water, which should have caused the $\delta^{18} \mathrm{O}$ signal of the thick shells to increase. This appears not to be the case as the $\delta^{18} \mathrm{O}$ values of the thick shells are actually slightly (though not statistically significant) lower than those of the thin shells.

\subsection{Selective fragmentation/dissolution}

An alternative mechanism that could potentially explain the age difference found between the thick and thin shells, and is in line with the $\delta^{18} \mathrm{O}$ observations, is by selective carbonate removal. Dissolution or fragmentation of foraminiferal shells in the mixed layer of the sediment could gradually dissolve and/or break up shells. Such a process would mainly affect the less resistant, and/or thinner, shells, selectively removing them from the sediment. Assuming that shells initially differed in wall thickness and weight, the average age of the thin walled shells that escaped dissolution/fragmentation will be younger than that of the more resistant thick ones, just like observed. The shells in the sediment, however, generally look well preserved, some with remnants of spines still present. Fragmentation and dissolution are known to change faunal assemblages (Berger, 1970; Anderson and Archer, 2002; Le and Thunell, 1996), and susceptibility for it is related to the thickness of the shell walls (Barker et al., 2007). However, Conan et al. (2002) showed that exactly at this site the abundance of dissolution sensitive species in the surface sediment is high and there is a close similarity between foraminifera assemblages and skeletal group compositions in the surface sediment and in an on-site sediment trap. This implies a good preservation without selective removal of susceptible carbonate components (i.e. thin walled shells) in the sediment. Furthermore, the higher shell weights below the mixed layer cannot be explained by selec- tive fragmentation/dissolution either as the foraminifera fragment based dissolution index $F(\%)$ shows no change down core (Fig. 1). Although selective fragmentation/dissolution may have caused an age offset between thick and thin shells, there are no indications that such a process played a principal role at our site, nor can it explain the increase in shell weight below the mixed layer unless the process has intensified recently.

\subsection{Seasonality}

The variation in shell weight and wall thickness observed in the top sediment may also be the result of monsoonal changes in water properties from upwelling to non-upwelling conditions. Comparison with shells from the sediment trap for the same size fraction $(255-350 \mu \mathrm{m})$ shows that the differences found between shells that have calcified during the monsoon season and the inter-monsoon season(s) are similar to the differences found between the thick and thin shells in the core top (Table 2). In addition, the flux corrected average of the entire nine month series is strikingly close to shells weights found in samples from the surface water $(11.5 \mu \mathrm{g}$, Conan, 2006) near the coring site (906, taken February 1993), and similar to the mean shell weight from the mixed layer of sediment core 905B (Table 2). In other words, seasonality produces similar differences in shell weight and stable isotopes as found between the thick and thin shells. Furthermore recent shells from the water column and sediment trap have weights similar to those found in the modern mixed layer. This is in contrast with the acidification hypothesis, which would predict recent shells from the water column to have lower shell weights compared to those in the sediment (which is a mixture of recent and pre-anthropogenic shells). It should be noted that plankton tow samples and sediment 
trap represent snapshots in time and do not capture the interannual to multidecadal variability, which is captured in the sediment averages. Comparison between weights from the water column and the sediment could therefore be misleading (1992/93 could have been a very 'heavy' year for instance). The heavy weights in recent shells remains inconsistent with the acidification hypothesis however.

Seasonal production can thus explain the differences found in shell weight and stable isotopes, and is in line with data from the water column. However, seasonal upwelling cannot explain the increase in shell weight between the mixed layer and below. As upwelling has been generally intense (and continuous) during the last $10 \mathrm{ka}$ (Jung et al., 2002; Ivanochko et al., 2005), light shells would be expected to occur at all levels in the sediment core as well, especially since there is no indication for selective removal in the sediment. Furthermore, the radiocarbon data show that the distinction between thin and thick walled shells from the top of sediment core BC21WP7 is most probably not entirely due to seasonal upwelling. As subsurface upwelling waters have not been in contact with the atmosphere for some time, the radiocarbon signal is older, which should have resulted in older ${ }^{14} \mathrm{C}$ ages for light shells produced in upwelled waters. This is precisely opposite to our observation, which indicates that the thin walled shells have younger ${ }^{14} \mathrm{C}$ ages.

\section{Concluding remarks}

Our study provides a first indication that anthropogenic ocean acidification may have affected the calcification of foraminifera in the surface ocean. However, a scenario with seasonal production of thick and thin shells also explains the observed changes in shell weight and wall thickness in the western Arabian Sea. While the seasonality scenario alone cannot explain the radiocarbon data (the light shells being younger) or the higher shell weights below the sediment mixed layer, the acidification hypothesis appears inconsistent with some observations from the water column. It is likely that the two processes take place simultaneously, making it difficult to unravel one from the other at our site, which is characterised by high seasonal variations. The radiocarbon analysis implies that, on top of the seasonal variation, a part of the observed differences is probably the result of anthropogenic ocean acidification. Further work on this subject is necessary to solve this problem and should ideally focus on sites with less pronounced seasonality unless the seasonal signal can be unravelled adequately.

If shell weights are indeed decreasing due to anthropogenic acidification, this effect is very likely to intensify in the future considering the projected rate and magnitude of future acidification (Caldeira and Wickett, 2003; Orr et al., 2005). Biological consequences for planktic foraminifera and other marine calcifying organisms are currently being investigated but are still uncertain. Nevertheless, if seawater acidification will have similar effects in the natural environment as observed in laboratory studies, this will have a profound impact on global carbonate production (Feely et al., 2004).

Acknowledgements. We thank Wim de Boer of the Royal Netherlands Institute for Sea Research for the ${ }^{210} \mathrm{~Pb}$ data and discussion on bioturbation and Saskia Kars for the SEM photography. Howie Spero is thanked for his valuable comments and suggestions on earlier versions of the manuscript. The participants of the first Fast Track Initiative IGBP-SCOR workshop (28-30 September 2006) on ocean acidification at Lamont Doherty Earth Observatory are thanked for discussion and valuable feedback. We also like to thank two anonymous reviewers for their comments on the manuscript. This is a contribution to the "European Project on Ocean Acidification” (EPOCA)(FP7/ 211384).

Edited by: A. Neftel

\section{References}

Anderson, D. M. and Archer, D.: Glacial-interglacial stability of ocean $\mathrm{pH}$ inferred from foraminifer dissolution rates, Nature, 416(6876), 70-73, 2002.

Asami, R., Yamada, T., Iryu, Y., Quinn, T. M., Meyer, C. P., and Paulay, G.: Interannual and decadal variability of the western Pacific sea surface condition for the years 1787-2000: Reconstruction based on stable isotope record from a Guam coral, J. Geophys. Res.-Oceans, 110(C), 5 pp., 2005.

Barker, S. and Elderfield, H.: Foraminiferal Calcification Response to Glacial-Interglacial Changes in Atmospheric CO2, Science, 297(5582), 833-836, 2002.

Barker, S., Broecker, W., Clark, E., and Hajdas, I.: Radiocarbon age offsets of foraminifera resulting from differential dissolution and fragmentation within the sedimentary bioturbated zone, $\mathrm{Pa}$ leoceanography, 22, 2 pp., 2007.

Berger, W. H.: Planktonic Foraminifera: Selective solution and the lysocline, Mar. Geol., 8, 111-138, 1970.

Beveridge, N. A. S. and Shackleton, N. J.: Carbon isotopes in recent planktonic foraminifera: A record of anthropogenic $\mathrm{CO} 2$ invasion of the surface ocean, Earth Planet. Sc. Lett., 126(4), 259-273, 1994.

Bijma, J., Spero, H. J., and Lea, D. W.: Reassessing Foraminiferal Stable Isotope Geochemistry: Impact of the Oceanic Carbonate System, in: Use of Proxies in Paleoceanography: Examples of the South Atlantic, edited by: Fisher, G. and Wefer, G., SpringerVerlag, New York, 489-512, 1999.

Bohm, F., Joachimski, M. M., Lehnert, H., Morgenroth, G., Kretschmer, W., Vacelet, J., and Dullo, W.-C.: Carbon isotope records from extant Caribbean and South Pacific sponges: Evolution of [delta]13C in surface water DIC, Earth Planet. Sc. Lett., 139(1-2), 291-303, 1996.

Bohm, F., Haase-Schramm, A., Eisenhauer, A., Dullo, W. C., Joachimski, M. M., Lehnert, H., and Reitner, J.: Evidence for preindustrial variations in the marine surface water carbonate system from coralline sponges, Geochem. Geophy. Geosy., 3, 3 pp., art.-no. 1019, 2002.

Broecker, W. S. and Olson, E. A.: Radiocarbon from Nuclear Tests, II, Science, 132(3429), 712-721, 1960. 
Caldeira, K. and Wickett, M. E.: Oceanography: Anthropogenic carbon and ocean pH, Nature, 425(6956), 365 pp., 2003.

Conan, S. M.-H., Ivanova, E. M., and Brummer, G.-J. A.: Quantifying carbonate dissolution and calibration of foraminiferal dissolution indices in the Somali Basin, Mar. Geol., 182(3-4), 325349, 2002.

Conan, S. M.-H.: Calibration of planktic foraminifera proxies for paleoproductivity and seasonal variability in the western Arabian Sea, Faculty of Earth and Life Sciences, Vrije Universiteit, Amsterdam, 225 pp., 2006.

Druffel, E. R. M. and Benavides, L. M.: Input of excess $\mathrm{CO} 2$ to the surface ocean based on $13 \mathrm{C} / 12 \mathrm{C}$ ratios in a banded Jamaican sclerosponge, 321(6065), 58-61, 1986.

Etheridge, D. M., Steele, L. P., Langenfelds, R. L., Francey, R. J., Barnola, J.-M., and Morgan, V. I.: Historical CO2 records from the Law Dome DE08, DE08-2, and DSS ice cores, in: Trends: A Compendium of Data on Global Change, Carbon Dioxide Information Analysis Center, Oak Ridge National Laboratory, U.S. Department of Energy, Oak Ridge, Tenn., USA, 1998.

February, E. C. and Stock, W. D.: Declining Trend in the 13C/12C Ratio of Atmospheric Carbon Dioxide from Tree Rings of South African Widdringtonia cedarbergensis, Quaternary Res., 52(2), 229-236, 1999.

Feely, R. A., Sabine, C. L., Lee, K., Berelson, W., Kleypas, J., Fabry, V. J., and Millero, F. J.: Impact of Anthropogenic CO2 on the CaCO3 System in the Oceans, Science, 305(5682), 362366, 2004.

Feng, X. and Epstein, S.: Carbon isotopes of trees from arid environments and implications for reconstructing atmospheric $\mathrm{CO} 2$ concentration, Geochim. Cosmochim. Ac., 59(12), 2599-2608, 1995.

Francey, R. J., Allison, C. E., Etheridge, D. M., Trudinger, C. M., Enting, I. G., Leuenberger, M., Langenfelds, R. L., Michel, E., and Steele, L. P.: A 1000-year high precision record of d13C in atmospheric CO2, Tellus B, 51(2), 170-193, 1999.

Friedli, H., Lotscher, H., Oeschger, H., Siegenthaler, U., and Stauffer, B.: Ice core record of the $13 \mathrm{C} / 12 \mathrm{C}$ ratio of atmospheric $\mathrm{CO} 2$ in the past two centuries, 324(6094), 237-238, 1986.

Gazeau, F., Quiblier, C., Jansen, J. M., Gattuso, J. P., Middelburg, J. J., and Heip, C. H. R.: Impact of elevated $\mathrm{CO} 2$ on shellfish calcification, Geophys. Res. Lett., 34(7), L07603, doi:10.1029/2006GL028554, 2007.

Gruber, N., Keeling, C. D., Bacastow, R. B., Guenther, P. R., Lueker, T. J., Wahlen, M., Meijer, H. A. J., Mook, W. G., and Stocker, T. F.: Spatiotemporal patterns of carbon-13 in the global surface oceans and the oceanic Suess effect, Global Biogeochem. Cy., 13(2), 307-335, 1999.

Grumet, N. S., Guilderson, T. P., and Dunbar, R. B.: Meridional transport in the Indian Ocean traced by coral radiocarbon, J. Mar. Res., 60(5), 725-742, 2002.

Grumet, N. S., Abram, N. J., Beck, J. W., Dunbar, R. B., Gagan, M. K., Guilderson, T. P., Hantoro, W. S., and Suwargadi, B. W.: Coral radiocarbon records of Indian Ocean water mass mixing and wind-induced upwelling along the coast of Sumatra, Indonesia, J. Geophys. Res.-Oceans, 109(C5), C05003, doi:10.1029/2003JC002087, 2004.

Hughen, K. A., Baillie, M. G. L., Bard, E., Beck, J. W., Bertrand, C. J. H., Blackwell, P. G., Buck, C. E., Burr, G. S., Cutler, K. B., Damon, P. E., Edwards, R. L., Fairbanks, R. G., Friedrich,
M., Guilderson, T. P., Kromer, B., McCormac, G., Manning, S., Ramsey, C. B., Reimer, P. J., Reimer, R. W., Remmele, S., Southon, J. R., Stuiver, M., Talamo, S., Taylor, F. W., van der Plicht, J., and Weyhenmeyer, C. E.: Marine04 marine radiocarbon age calibration, 0-26 cal kyr BP, Radiocarbon, 46(3), 10591086, 2004.

Ivanochko, T. S., Ganeshram, R. S., Brummer, G.-J. A., Ganssen, G., Jung, S. J. A., Moreton, S. G., and Kroon, D.: Variations in tropical convection as an amplifier of global climate change at the millennial scale, Earth Planet. Sc. Lett., 235(1-2), 302-314, 2005.

Ivanova, E.: Late Quaternary monsoon history and paleoproductivity of the western Arabian Sea, Faculty of Earth Sciences, Free University, Amsterdam, 172 pp., 1999.

Ivanova, E., Ganssen, G. M., Jung, S. J. A., and Reichart, G. J.: High-resolution paleomonsoon record of the past 30ka in the western Arabian Sea, in: Late Quaternary monsoon history and paleoproductivity of the western Arabian Sea, Faculty of Earth Sciences, Amsterdam, 2000.

Jung, S. J. A., Davies, G. R., Ganssen, G. M., and Kroon, D.: Centennial-millennial scale monsoon variations off Somalia over the last $35 \mathrm{kyr}$, in: Tectonic and Climatic Evolution of the Arabian Sea Region, edited by: Clift, P. and Kroon, D., J. Geol. Soc. London, London, 341-352, 2002.

Kalish, J. M., Nydal, R., Nedreaas, K. H., Burr, G. S., and Eine, G. L.: A time history of pre- and post-bomb radiocarbon in the Barents Sea derived from Arcto-Norwegian cod otoliths, Radiocarbon, 43(2B), 843-855, 2001.

Keeling, C. D., Mook, W. G., and Tans, P. P.: Recent trends in the $13 \mathrm{C} / 12 \mathrm{C}$ ratio of atmospheric carbon dioxide, 277(5692), 121123, 1979.

Key, R. M. and Quay, P.: U.S. WOCE Indian Ocean Survey: Final Report for Radiocarbon, Princeton University, Princeton, 22, 2002.

Kortzinger, A., Quay, P. D., and Sonnerup, R. E.: Relationship between anthropogenic $\mathrm{CO} 2$ and the $\mathrm{C}-13$ suess effect in the North Atlantic Ocean, Global Biogeochem. Cy., 17, 1 pp., 2003.

Kuhnert, H., Patzold, J., Hatcher, B., Wyrwoll, K. H., Eisenhauer, A., Collins, L. B., Zhu, Z. R., and Wefer, G.: A 200-year coral stable oxygen isotope record from a high-latitude reef off western Australia, Coral Reefs, 18(1), 1-12, 1999.

Langdon, C. and Atkinson, M. J.: Effect of elevated $\mathrm{pCO}(2)$ on photosynthesis and calcification of corals and interactions with seasonal change in temperature/irradiance and nutrient enrichment, J. Geophys. Res.-Oceans, 110(C9), C09S07, doi:10.1029/2004JC002576, 2005.

Le, J. N. and Thunell, R. C.: Modelling planktic foraminiferal assemblage changes and application to sea surface temperature estimation in the western equatorial Pacific Ocean, Mar. Micropaleontol., 28(3-4), 211-229, 1996.

Leavitt, S. W. and Lara, A.: South American tree rings show declining $\delta 13 \mathrm{C}$ trend, Tellus B, 46(2), 152-157, 1994.

Luthi, D., Le Floch, M., Bereiter, B., Blunier, T., Barnola, J.-M., Siegenthaler, U., Raynaud, D., Jouzel, J., Fischer, H., Kawamura, K., and Stocker, T. F.: High-resolution carbon dioxide concentration record 650,000-800,000[thinsp]years before present, Nature, 453(7193), 379-382, 2008.

Moos, C.: Reconstruction of upwelling intensity and paleo-nutrient gradients in the northwest Arabian Sea derived from stable 
carbon and oxygen isotopes of planktic foraminifera, Geowissenschaften, Universitat Bremen, Bremen, 103 pp., 2000.

NIOP: Tracing a seasonal upwelling - report on two cruises of RV Tyro to the NW Indian Ocean in 1992 and 1993, National Museum of Natural History, Leiden, 146, 1995.

Nozaki, Y., Rye, D. M., Turekian, K. K., and Dodge, R. E.: 200Year Record of C-13 and C-14 Variations in a Bermuda Coral, Geophys. Res. Lett., 5(10), 825-828, 1978.

O'Leary, M. H.: Carbon isotope fractionation in plants, Phytochemistry, 20(4), 553-567, 1981.

Orr, J. C., Fabry, V. J., Aumont, O., Bopp, L., Doney, S. C., Feely, R. A., Gnanadesikan, A., Gruber, N., Ishida, A., Joos, F., Key, R. M., Lindsay, K., Maier-Reimer, E., Matear, R., Monfray, P., Mouchet, A., Najjar, R. G., Plattner, G.-K., Rodgers, K. B., Sabine, C. L., Sarmiento, J. L., Schlitzer, R., Slater, R. D., Totterdell, I. J., Weirig, M.-F., Yamanaka, Y., and Yool, A.: Anthropogenic ocean acidification over the twenty-first century and its impact on calcifying organisms, 437(7059), 681-686, 2005.

Peeters, F. J. C., Brummer, G.-J. A., and Ganssen, G.: The effect of upwelling on the distribution and stable isotope composition of Globigerina bulloides and Globigerinoides ruber (planktic foraminifera) in modern surface waters of the NW Arabian Sea, Global Planet. Change, 34(3-4), 269-291, 2002.

Petit, J. R., Jouzel, J., Raynaud, D., Barkov, N. I., Barnola, J.-M., Basile, I., Bender, M., Chappellaz, J., Davis, M., Delaygue, G., Delmotte, M., Kotlyakov, V. M., Legrand, M., Lipenkov, V. Y., Lorius, C., PEpin, L., Ritz, C., Saltzman, E., and Stievenard, M.: Climate and atmospheric history of the past 420,000 years from the Vostok ice core, Antarctica, Nature, 399(6735), 429436, 1999.

Quay, P., Sonnerup, R., Westby, T., Stutsman, J., and McNichol, A.: Changes in the C-13/C-12 of dissolved inorganic carbon in the ocean as a tracer of anthropogenic $\mathrm{CO} 2$ uptake, Global Biogeochem. Cy., 17, 1 pp., 2003.

Quay, P. D., Tilbrook, B., and Wong, C. S.: Oceanic Uptake of Fossil-Fuel CO2 - C-13 Evidence, Science, 256(5053), 74-79, 1992.

Riebesell, U., Zondervan, I., Rost, B., Tortell, P. D., Zeebe, R. E., and Morel, F. M. M.: Reduced calcification of marine plankton in response to increased atmospheric CO2, 407(6802), 364-367, 2000 .
Rosenzweig, C., Casassa, G., Karoly, D. J., Imeson, A., Liu, C., Menzel, A., Rawlins, S., Root, T. L., Seguin, B., and Tryjanowski, P.: Assessment of observed changes and responses in natural and managed systems, in: Climate Change 2007: Impacts, Adaptation and Vulnerability, Contribution of Working Group II to the Fourth Assessment Report of the Intergovernmental Panel on Climate Change, edited by: Parry, M. L., Canziani, O. F., Palutikof, J. P., Van der Linden, P. J., and Hanson, C. E., Cambridge University Press, Cambridge, UK, 79-131, 2007.

Sabine, C. L., Feely, R. A., Gruber, N., Key, R. M., Lee, K., Bullister, J. L., Wanninkhof, R., Wong, C. S., Wallace, D. W. R., Tilbrook, B., Millero, F. J., Peng, T. H., Kozyr, A., Ono, T., and Rios, A. F.: The oceanic sink for anthropogenic CO2, Science, 305(5682), 367-371, 2004.

Soetaert, K., Herman, P. M. J., Middelburg, J. J., Heip, C., deStigter, H. S., vanWeering, T. C. E., Epping, E., and Helder, W.: Modeling Pb-210-derived mixing activity in ocean margin sediments: Diffusive versus nonlocal mixing, J. Mar. Res., 54(6), 1207-1227, 1996.

Spero, H. J.: Do Planktic Foraminifera Accurately Record Shifts in the Carbon Isotopic Composition of Seawater Sigma-Co2, Mar. Micropaleontol., 19(4), 275-285, 1992.

Spero, H. J., Bijma, J., Lea, D. W., and Bemis, B. E.: Effect of seawater carbonate concentration on foraminiferal carbon and oxygen isotopes, Nature, 390(6659), 497-500, 1997.

Stuiver, M. and Ostlund, H. G.: GEOSECS Indian Ocean and Mediterranean radiocarbon, Radiocarbon, 25(1), 1-29, 1983.

Van Weering, T. C. E., Berger, G. W., and Kalf, J.: Recent sediment accumulation in the Skagerrak, Northeastern North Sea, Neth. J. Sea Res., 21(3), 177-189, 1987.

Wang, L. J.: Isotopic signals in two morphotypes of Globigerinoides ruber (white) from the South China Sea: implications for monsoon climate change during the last glacial cycle, Palaeogeogr. Palaeocl., 161(3-4), 381-394, 2000.

Wolf-Gladrow, D. A., Riebesell, U., Burkhardt, S., and Bijma, J.: Direct effects of $\mathrm{CO} 2$ concentration on growth and isotopic composition of marine plankton, Tellus B, 51(2), 461-476, 1999.

Zeebe, R. E. and Wolf-Gladrow, D.: $\mathrm{CO}_{2}$ in Seawater: Equilibrium, Kinetics, Isotopes, Elsevier Oceanography Series, Elsevier, Amsterdam, 346 pp., 2001. 